\title{
A influência do plurilinguismo na L1 - ou por que o padrão monolíngue já não se aplica
}

Marina GRILLI (®)

Universidade de São Paulo (USP)

\section{RESUMO}

Esta palestra apresenta razões pelas quais deveríamos descartar dicotomias tradicionais na pesquisa em Linguística, como monolíngue versus plurilíngue, nativo versus não-nativo, inato versus aprendido, fatores biológicos versus culturais. Argumenta-se que, em vez disso, deveríamos entender o plurilinguismo como um continuum, indo do menos plurilíngue ao mais plurilíngue. A razão para tanto é que o monolinguismo tem se tornado cada vez mais raro, pois cada vez mais pessoas aprender outras línguas ou são simplesmente expostas ao multilinguismo em sociedade. Consequentemente, o plurilinguismo é considerado aqui de modo amplo, enquanto sinônimo da capacidade de lidar com mais de uma língua em qual-

EDITADO POR quer idade, e não apenas desde o nascimento. A conferencista conclui, novamente, que não faz sentido tomar o falante nativo como modelo a ser seguido pelo aprendiz de uma língua.

\section{ABSTRACT}

This lecture presents reasons why we should all abandon traditional dichotomies in Linguistics research, such as monolingual versus multilingual, native versus non-native, innate versus learned, biological versus cultural factors. It is argued that we should rather understand multilingualism a continuum, ranging from less multilingual to more multilingual, and the reason for it is that real monolingualism is becoming rarer because more people learn other languages or are simply exposed to multilingualism in society. Consequently, multilingual is to be considered here in a broad sense, as a synonym to being able to handle more than one language 


\section{REVISTA DA ABRALIN}

at any age, and not only from birth. The lecturer concludes, again, that the native speaker as a role model to be followed by language learners does not make sense.

PALAVRAS-CHAVE

Monolinguismo. Plurilinguismo. Falante nativo.

KEYWORDS

Monolingualism. Multilingualism. Native speaker.

A conferencista Antonella Sorace inicia colocando três perguntas retóricas: monolíngues nativos são todos iguais? Monolíngues nativos são iguais durante toda a vida? E monolíngues nativos ainda existem, ou estão sob risco de extinção? A maior parte das pesquisas experimentais em Linguística compara plurilíngues a monolíngues, bem como falantes nativos a não-nativos. Além disso, muitos estudos quantitativos presumem que os falantes entre os quais se estabelecem comparações são homogêneos - ainda que a norma monolíngue e os problemas que ela traz consigo já tenham sido discutidos à exaustão.

O padrão do nativo monolíngue deriva majoritariamente do fato de que grande parte da pesquisa em Linguística nos últimos cinquenta anos foi realizada em países ocidentais monolíngues, muitos dos quais pertencentes à chamada anglosfera. Esse ponto é particularmente interessante, ao considerarmos que a epistemologia ocidental é um produto da colonialidade. De acordo com Mignolo (2011), o conceito de diferentes raças humanas foi inventado por europeus que buscavam dominar outros povos, convencendo todo o mundo de que havia raças superiores e raças inferiores. Seguindo a mesma lógica, as línguas foram divididas e classificadas como parte do plano de impor as línguas europeias às comunidades colonizadas. Assim, todo o conhecimento não-ocidental já consolidado, bem como os modos não-ocidentais de produzir conhecimento, foram desacreditados e considerados marginais (CANAGARAJAH, 2017).

Portanto, a norma sobre a qual as pesquisas sobre plurilinguismo têm se estabelecido são os chamados julgamentos de aceitabilidade, que partem da concepção de que há falantes nativos plenamente competentes, e de que estes são capazes de julgar se uma afirmação está correta ou incorreta. De acordo com essa visão, o mais alto nível de proficiência possível é o nível similar ao nativo, que, afinal, ainda significa "quase lá". Essa noção tem sido questionada pelas últimas pesquisas sobre as impressionantes competências de tradutores profissionais não-nativos.

Sorace distingue dois grandes motivos pelos quais o monolíngue nativo enquanto padrão é um problema. O primeiro deles é que o plurilinguismo deveria ser analisado como um continuum que abrange do menos plurilíngue ao mais plurilíngue, e não como uma categoria aristotélica estanque. Nas atuais pesquisas em plurilinguismo, tanto na Linguística como em outras ciências como a 


\section{REVISTA DA ABRALIN}

psicologia e a ciência cognitiva, as interferências entre línguas no repertório de um falante costumam ser tratadas como vantagens ou desvantagens, e essas definições refletem a norma monolíngue enquanto princípio.

Em segundo lugar, já foi provado que aprender uma L2 exerce influência sobre a L1 do falante. Isso contradiz a ideia de que a competência linguística do falante nativo é estável e permanece o mesmo por toda a vida. Em outras palavras, as línguas que compõem o repertório de um falante interagem de diversas formas, tanto da chamada L1 para as línguas aprendidas recentemente como no sentido contrário. Os conceitos de competência nativa e habilidades na L2 são igualmente fluidos e muito menos estáveis do que se imagina, com influências em ambos os sentidos, condicionadas por uma série de parâmetros que incluem a proficiência, a idade da aquisição e a frequência de uso.

Pesquisas recentes mostram que esses efeitos dependem de vários critérios, nem todos plenamente desvendados. A proximidade entre línguas os explica apenas parcialmente, e outros fatores como a idade da aquisição e o nível de proficiência podem provar-se relevantes assim que houver mais dados disponíveis a respeito.

Portanto, mesmo as nomenclaturas L1 e L2 são questionáveis.

No caso de migrantes, que adotaram a segunda língua após um período transitório, foi observado que sua competência linguística na L1 pode sofrer mudanças e assemelhar-se à competência de um falante avançado. A convergência de estruturas linguísticas oriundas de ambas as línguas é influenciada pela pragmática e pelo contexto. Entretanto, esse tipo de mudança é reversível por meio da reimersão desses falantes em suas comunidades de origem. Dessa forma, não se trata de uma perda ou erosão da gramática, efeito comumente denominado atrito (attrition) em estudos da Linguística que partem de uma perspectiva monolíngue.

Sorace ilustra a interferência de ordem pragmática por meio do contraste entre duas línguas: uma língua em que o uso dos pronomes obrigatório e outra em que é opcional. O uso dos pronomes por um falante de ambas as línguas deixa transparecer diferenças sutis quanto à língua de referência do falante: em casos como esse, o falante plurilíngue tende a optar por evitar uma possível ambiguidade, aplicando as regras da língua na qual os pronomes são obrigatórios. A fim de transmitir a mensagem com eficácia, o falante evita a ambiguidade optando pela redundância.

Outro fator que precisa ser mais bem compreendido por meio de futuras pesquisas é a relação entre integração e controle inibitório em falantes plurilíngues. O controle inibitório é a habilidade de excluir uma língua ao comunicar-se em outra, enquanto a integração se manifesta como tendência a misturar características das línguas envolvidas. Integração e inibição parecem ser, até certo ponto, mutuamente excludentes: quanto mais o falante tende a inibir, menor sua habilidade de integração, e vice versa.

Em suma, os estudos apresentados colocam em xeque a utilidade de conceitos como 'monolinguismo' e 'falante nativo', sugerindo que monolíngues nativos não são todos iguais, nem permanecem iguais durante toda a vida. Considerando as interferências estatisticamente significativas entre as línguas do repertório de um falante, ainda que o nível de proficiência seja baixo, é possível questionar se falantes monolíngues constituem, realmente, a norma, ou sequer existem. 


\section{REVISTA DA ABRALIN}

Se as características monolíngue e nativo não são tão estáveis quanto têm sido consideradas até hoje, e considerando que os modos monolíngue e multilíngue têm dinâmicas completamente diferentes e não podem ser explicados a partir dos mesmos parâmetros, temos mais um excelente motivo para não tomar o falante monolíngue ou nativo como ponto de referência para investigar as propriedades universais das linguagens humanas.

\section{REFERÊNCIAS}

THE 'Native Monolingual Standard' In Language Research (and Why It's a Problem). Conferência apresentada por Antonella Sorace [s.l., s.n], 2020. 1 vídeo (1h32min10s). Publicado pelo canal da Associação Brasileira de Linguística. Disponível em: https://youtu.be/PpSiOlSSISc. Acesso em: 7 jul. 2020.

CANAGARAJAH, S. Translingual Practices and Neoliberal Policies. Attitudes and Strategies of African Skilled Migrants in Anglophone Workplaces. Springer, 2017.

MIGNOLO, W. The Darker Side of Western Modernity. Durham/London: Duke University Press, 2011. 